\title{
Waterfowl and flood extent in the Hadejia-Nguru wetlands of north-east Nigeria
}

\author{
GERT POLET
}

\section{Summary}

The Hadejia-Nguru wetlands in north-east Nigeria are of international importance for resident and migratory Anatidae but the construction of large dams upstream seriously threatens their continued existence. An analysis of waterfowl census data collected over the period 1988 to 1998 inclusive demonstrated that the extent of flooding had no effect on the species richness of waterfowl but had a significant impact on total numbers. White-faced Whistling Duck Dendrocygna viduata and Garganey Anas querquedula in particular respond to changes in flood extent. The present practice of releasing water from upstream reservoirs should therefore be continued.

\section{Introduction}

Based on the Ramsar Convention 3c criteria (Perennou 1991), the Hadejia-Nguru wetlands are of international importance for breeding and wintering waterfowl. However, it was considered that the construction of two large reservoirs upstream might result in reduced peak discharges and hence reduced flooding of the wetlands, thus negatively affecting the ecosystem's integrity, including the livelihood of the estimated one million people in the local communities. The region's farming system is based on the natural inundation of the area, rice being planted with the rising waters, followed by a range of other crops after the waters have receded.

Recognizing these issues, the Royal Society for the Protection of Birds and The World Conservation Union launched the Hadejia-Nguru Wetlands Conservation Project (HNWCP) in 1988, with the aim of maintaining the natural resources and functions of the Hadejia-Nguru wetlands. The project carries out hydrological, ecological and socio-economic surveys, as well as developing alternative sources of livelihood for the impoverished local population.

Hollis et al. (1993), Thompson (1995) and HNWCP (unpubl. report 1997) have demonstrated that the upstream impoundments have indeed resulted in a reduced flooding of the Hadejia-Nguru wetlands. To monitor the effects of reduced inundation the HNWCP conducted annual waterfowl counts over a period of 11 years. The present paper examines the relationship between waterfowl numbers and the extent of flooding.

\section{Study area and methods}

The Hadejia-Nguru wetlands are located at the confluence of the Hadejia and Jama'are rivers (Figure 1 ). The total area covers $5,100 \mathrm{~km}^{2}$, of which $3,000 \mathrm{~km}^{2}$ 


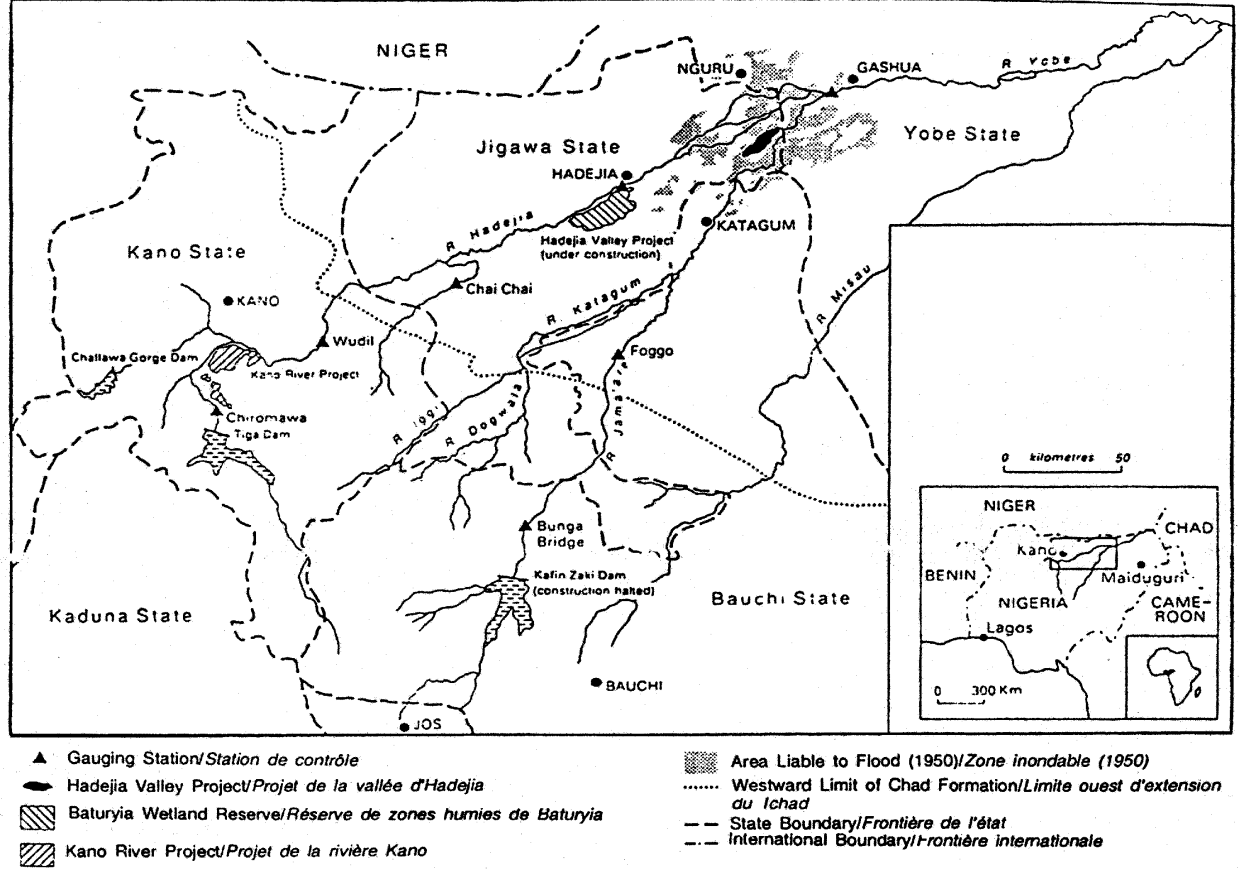

Figure 1. Location of the Hadejia-Nguru Wetlands (from Polet and Thompson 1996).

are liable to flooding shortly after the rainy season. The area consists of permanent and seasonal lakes and a complex pattern of floodplains, mudflats and marshes (Polet and Becker 1997). The Yobe river, formed by the convergence of the Jama'are and Hadejia rivers, leaves the Hadejia-Nguru wetlands at Gashua and drains into Lake Chad. A detailed description of the area is provided by Hollis et al. (1993).

The wetlands are characterized by various vegetation types. The higher land consists of Acacia seyal bushland and Andropogan spp. grasslands, with the characteristic doum palm Hyphaenae thebaica and baobab Adinsonia digitata present in large numbers. The wetter areas consist of Echinochloa spp. swamps, Oryza spp. and Vivaria spp. grasslands, and Ziziphus spp. scrubland. Emergent species in the lakes consist of Nymphaea spp. and floating mats of Ceratophyllum spp. (Garba Boyi and Polet 1996, G.P. et al. unpubl. report 1997).

From 1988 to 1998 , waterfowl have been counted annually in January over a period of about two weeks. The counts covered the whole of the inundated areas of the wetlands. Large open water-bodies and rivers were accessed by boat while drier areas were reached by vehicle or on foot. Over the years the survey teams got more familiar with the terrain, so it may be that pre-1991 results represent lower numbers of waterfowl than were actually present. Birds were counted individually as far as possible but, with large flocks, block-counts were made following Bibby et al. (1992). Observations were made from boats and high vantage points using binoculars and telescopes.

For 1987 and the period 1990 to 1997 flood extent figures were available for 
the peak of the inundation in October. In February the floods recede while water levels are at their lowest just before the rains arrive in July. In a given year, waterfowl numbers depend on wetlands fed by the floods of the previous summer so, for example, the waterfowl count in January 1998 is related to the flood extent of October 1997. Flood data were derived from aerial surveys with the same flight path pattern followed each year at a height of 1,200-1,500 m above the ground. The same Cessna 172 aircraft fitted with a Global Positioning System was used every year and each survey took about 10 flying hours. Within the total area, the inundated area was sketched on detailed maps (approximately 1:30,000) and thus the maximum flood extent was obtained each year using Global Information Systems. Each survey had a similar level of accuracy. Accuracy was validated further by Goes and Zabudum (unpubl. report 1997) who found a strong correlation between the measured flood extent figures and the total flow of water through the river system into the wetlands.

\section{Results}

Table 1 shows the numbers of waterfowl present for the period 1988 to 1998 . Seventeen species of waterfowl have been recorded in the Hadejia-Nguru wetlands with, on average, 12 species encountered each year. The most numerous were Garganey Anas querquedula, White-faced Whistling Duck Dendrocygna viduata and Northern Pintail Anas acuta. Other species in large numbers included Fulvous Whistling Duck Dendrocygna bicolor, Spur-winged Goose Plectopterus gambensis, Comb Duck Sarkidiornis melanotos, Ferruginous Duck Aythya nyroca and Northern Shoveler Anas clypeata. The presence of Hottentot Teal Anas hottentotta confirms the existence of an isolated population in northern Nigeria. Mallard Anas platyrhynchos was encountered in the Hadejia-Nguru wetlands by Debski (1995) in 1995, the first record for Nigeria. Other rare species for the area included Gadwall Anas strepera, Egyptian Goose Alopochen aegyptiacus and African Pygmy Goose Nettapus auritus.

The total number of waterfowl in the area ranged from 19,807 (1989) to 229,914 (1997). The period 1988 to 1995 was part of a longer period of dry years in the area (Table 1) but the flood extent was also severely reduced by the Tiga Dam upstream (Hollis et al. 1993, Thompson 1995). Prior to the construction of this dam and its associated irrigation scheme, the Hadejia-Nguru wetlands were inundated to an extent of about 2,000 $\mathrm{km}^{2}$, a magnitude that has never been observed since. In 1992 a second major dam, the Challawa Gorge Dam was closed on the Kano river, upstream of the wetlands. During 1993 and 1994 the dam remained closed in order to fill up its reservoir and this resulted in the low flood levels recorded in the wetland in 1993 and 1994.

From 1994 onwards, the Nigerian authorities released excess water from the dams during the wet season to enhance the natural flooding regime in the Hadejia-Nguru wetlands, an action initiated by the Hadejia-Nguru Wetlands Conservation Project and evolved over time. The years 1995 and 1997 were wetter than average and a combination of larger amounts of rainfall and the wet season releases from the reservoirs resulted in much larger areas of inundation in the Hadejia-Nguru wetlands than in the preceding years.

There was no relationship between the annual number of species of waterfowl 


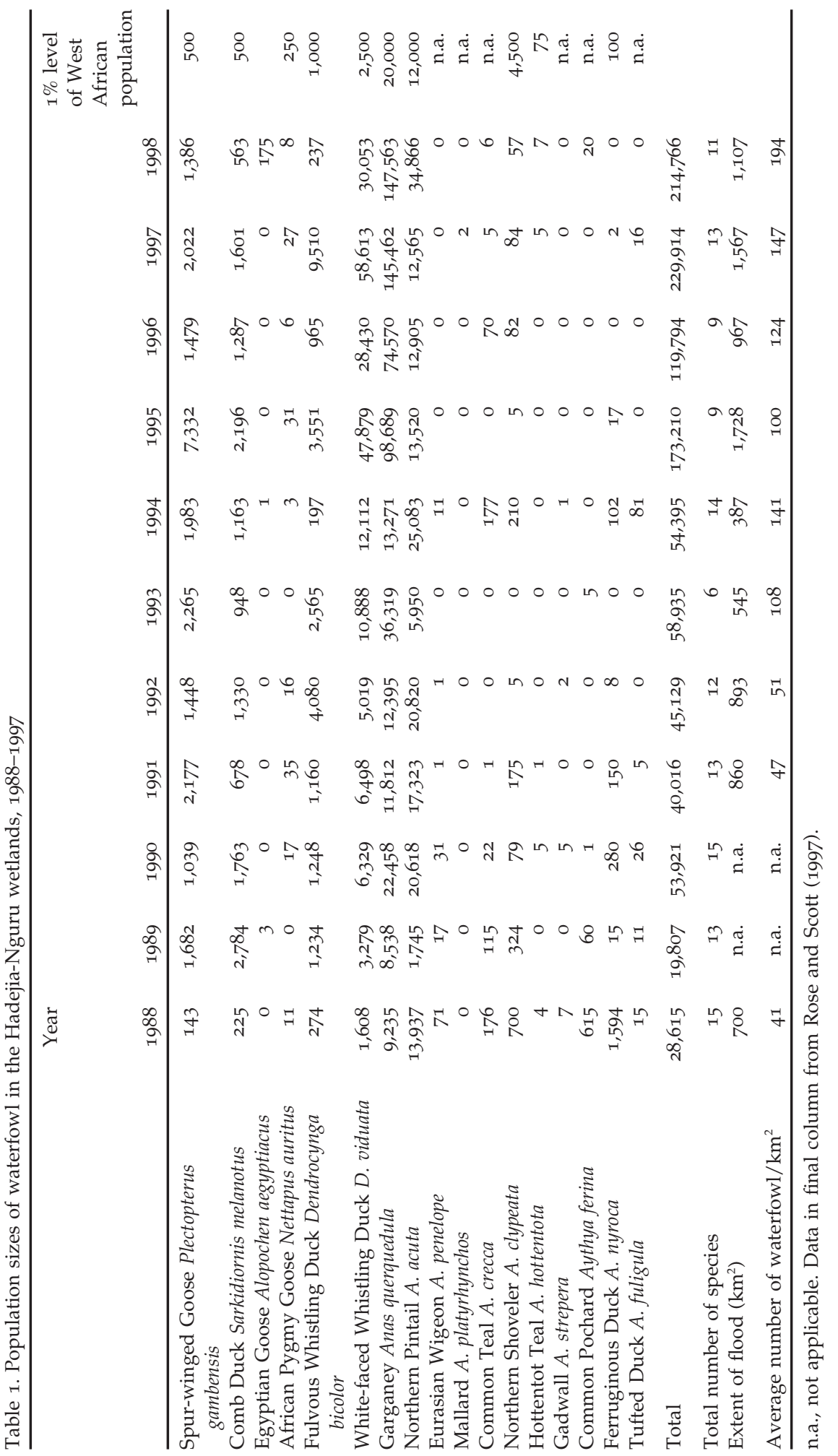




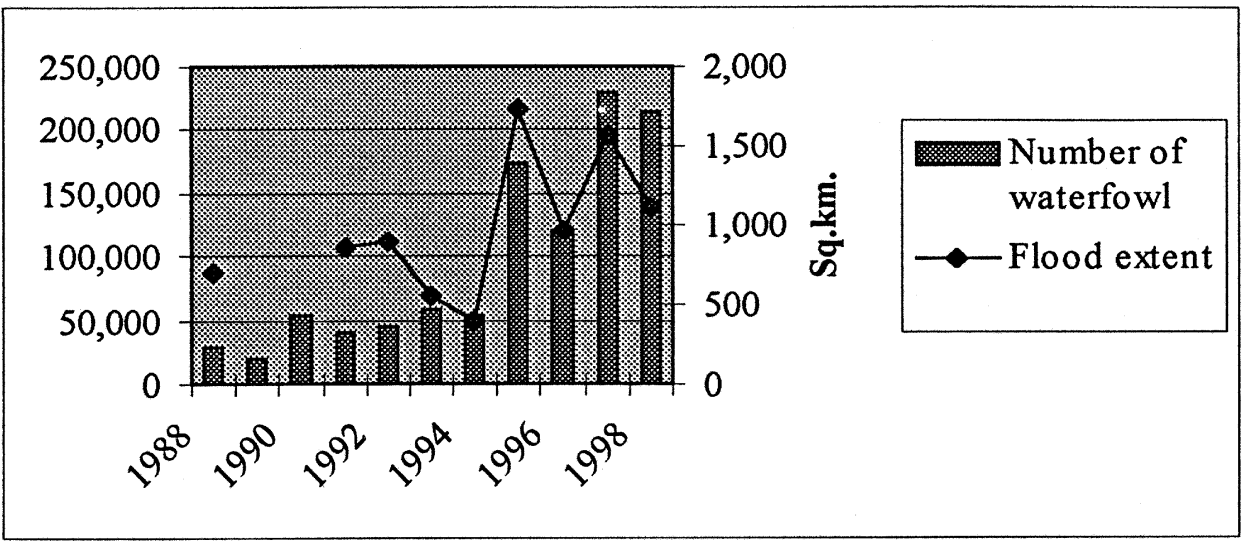

Figure 2. Waterfowl numbers and flood extent in the Hadejia-Nguru Wetlands 1988-1998.

recorded and the flood extent (Table $1 ; r^{2}=0.02, \mathrm{~ns}$ ); however, numbers of waterfowl present in the area roughly follow the flood extent trend over the years (Figure 2). If the extent of flooding is less than in previous year, the number of waterfowl present is also lower. This is especially clear from 1993-1998. There is a significant relationship between the total number of waterfowl present in the area and the extent of flooding $\left(r^{2}=0.625, d f=7, P<0.01\right)$. On average, every square kilometre of inundation held 110 waterfowl over the period.

The number of waterfowl per square kilometer ranged from 41 (1988) to 194 (1998) (Table 1). High densities were recorded during years of poor flooding (1993) as well as in years of good flooding (1997 and 1998). Relatively large numbers of waterfowl utilize the wetlands when flooding is low but, during such conditions, a smaller interface between dryland and wetland and a smaller area with shallow water provide prime feeding grounds for many waterfowl. Deteriorating food availability may have caused the birds to leave early, so not utilizing the area during the entire winter. High concentrations of waterfowl stay in the wetlands when they are in good condition. In years of extensive flooding, food availability can sustain large concentrations of waterfowl during the whole winter because inundations, spread over a wider area, create a larger interface between dryland and wetland and larger areas with shallow water. There appear to be two different levels of carrying capacity in the Hadejia-Nguru wetlands. If the flood extent is limited (less than $900 \mathrm{~km}^{2}$ ), a concentration of roughly 50 waterfowl $/ \mathrm{km}^{2}$ can be sustained but if flood extent is larger than $900 \mathrm{~km}^{2}$, there will be at least 100 waterfowl $/ \mathrm{km}^{2}$. Unfortunately there are no data on food availability.

During earlier periods (1988-1992), less than the expected numbers of waterfowl were encountered during surveys. It is known that the accuracy of surveys improved over time. To investigate the relationship between individual waterfowl species and flood extent, correlations were made between the two variables. Flooded area was significantly correlated with the numbers of Whitefaced Whistling Duck $\left(r^{2}=0.74, d f=7, P<0.001\right)$, Garganey $\left(r^{2}=0.56, d f=7, P<\right.$ 0.01) and African Pygmy Goose $\left(r^{2}=0.45, d f=7, P<0.05\right)$. There were no other significant relationships. 
Table 2. Overview of waterfowl species surpassing the Ramsar 1\% criteria (1988-1998)

\begin{tabular}{|c|c|c|c|c|c|c|c|c|c|c|c|c|}
\hline Species & 1988 & 1989 & 1990 & 1991 & 1992 & 1993 & 1994 & 1995 & 1996 & 1997 & 1998 & Total \\
\hline Spur-winged Goose & & * & * & * & * & * & * & * & * & * & * & 10 \\
\hline Comb Duck & & * & * & * & * & * & * & * & * & * & * & 10 \\
\hline $\begin{array}{l}\text { Fulvous Whistling } \\
\text { Duck }\end{array}$ & & * & $*$ & $*$ & * & * & & * & & * & & 7 \\
\hline $\begin{array}{l}\text { White-faced } \\
\text { Whistling Duck }\end{array}$ & & * & * & * & * & * & * & * & * & * & * & 10 \\
\hline Garganey & & & * & & & * & & * & * & $*$ & * & 6 \\
\hline Northern Pintail & * & & * & * & * & & * & * & * & * & * & 9 \\
\hline Ferruginous Duck & * & & * & * & & & * & & & & & 4 \\
\hline Total & 2 & 4 & 7 & 6 & 5 & 5 & 5 & 6 & 5 & 6 & 5 & 7 \\
\hline
\end{tabular}

\section{Discussion}

It is argued that inundations are beneficial to waterfowl populations and that the larger the area flooded, the more birds can be supported. However, there are few supporting data. Den Held (1981) demonstrated that fluctuations in Purple Heron Ardea purpurea numbers in The Netherlands coincided with fluctuations in flooded area of the Niger river inner delta in Mali.

The data presented here for the Hadejia-Nguru wetlands partly support the argument that there is a positive relationship between flood extent and waterfowl numbers. When the flood extent is less in the summer, the number of waterfowl in the following winter are reduced. However, the relationship is not linear; a $50 \%$ reduction in flood extent will not necessarily result in a halving of the number of waterfowl present. Also, the relationship does not hold for all species nor for species richness. In particular White-faced Whistling Duck (a resident species) and Garganey (a Palearctic migrant) showed variations in numbers with the extent of the flooded area. It is therefore neither resident nor migratory species which are especially sensitive to the annual area of flooding.

The release of water from upstream reservoirs not only contributes to the improvement of livelihoods of local communities but also enhances the ecological well-being of the wetlands downstream. The enhancement of natural flooding regimes in the Hadejia-Nguru wetlands will benefit the total population of waterfowl and certain species in particular. The release of water from the upstream reservoirs is therefore crucial to maintaining the ecological functions of this internationally important wetland.

Table 2 provides an overview of species which surpassed the Ramsar $1 \%$ criteria for each year, seven of the 17 species exceeding this threshold one or more times during the period of observation. Spur-winged Goose, Comb Duck and White-faced Whistling Duck populations are most consistent in meeting the $1 \%$ criteria, followed by Northern Pintail and Fulvous Whistling Duck. It is clear that the Hadejia-Nguru wetlands should be regarded as a wetland of international importance, as defined under the Ramsar Convention, and its future existence must be guaranteed.

\section{References}

Bibby, C. J., Burges N. D. and Hill, D. A. (1992) Bird census techniques. London: Academic Press. 
Debski, I. (1995) Mallard Anas platyrhynchos in Nigeria. Malimbus 17: 31-32.

Garba Boyi, M. and Polet, G. (1996) Afrotropical Anatidae population trends in the Hadejia-Nguru Wetlands, northern Nigeria (1988-1994). Gibier Faune Sauvage 13: 587-598.

Held, den J. J. (1981) Population changes in the Purple Heron in relation to drought in the wintering area. Ardea 69: 185-191.

Hollis, G. E., Adams, W. M. and Aminu-Kano, M., eds. (1993) The Hadejia-Nguru Wetlands, environment, economy and sustainable development of a Sahelian floodplain wetland. IUCN, Gland, Switzerland.

Perennou, C. (1991) Les recensements internationaux d'oiseaux d'eau en Afrique Tropicale. IWRB Special Publication 15.

Polet, G. and Becker, I. (1997) The Hadejia-Nguru Wetlands. Nigerian Field 62: 13-23.

Polet, G. and Thompson, J. R. (1996) Maintaining the floods. Hydrological and institutional aspects of managing the Komadugu-Yobe river basin and its floodplain wetlands. Pp. 73-100 in M. C. Acreman and G. E. Hollis, eds. Hydrological management and wetland conservation in Sub-Saharan Africa. Gland, Switzerland: IUCN.

Rose, P. M. and Scott D. A. (1997) Waterfowl population estimates. Second edition. Wageningen, The Netherlands: Wetlands International Publication 44.

Thompson, J. R. (1995) Hydrology, water management and wetlands of the HadejiaJama'are Basin, northern Nigeria. PhD thesis. University of London.

\section{GERT POLET}

IUCN-The World Conservation Union, Hadejia-Nguru Wetlands Conservation Project, Nigeria. Current address: WWF-Indochina Programme, 85 Tran Quoc Toan Street, District 3 Ho Chi Minh City, Vietnam; e-mail: gert-ina@wwfhcmc.vnn.vn 
